\title{
MENANGULANGI KEJAHATAN DENGAN APLIKASI ECONOMIC ANALYSIS OF LAW
}

Oleh :

\author{
Nurlely Darwis, SH, MSi \\ Dosen Tetap Fakultas Hukum Universitas Suryadarma Jakarta. \\ Kandidat Doktor Ilmu Hukum \\ Email : (nurlely.darwis@gmail.com)
}

\begin{abstract}
Abstrak:
Sinergitas ilmu hukum dan ilmu ekonomi dapat dijelaskan bahwa kedua bidang ilmu ini sama-sama menjelaskan tentang perilaku manusia, maka kedua ilmu ini memiliki korelasi (interdependen) untuk saling mendukung. Economic Analysis Of Law (EAL) menjelaskan tentang perluasan dimensi hukum melalui kajiannya, dalam konteks yang lebih luas EAL adalah melengkapi ajaran keadilan melalui konsepsi keadilan ekonomi. Oleh karena itu dalam hal menanggulangi kejahatan masa kini selayaknya menghukum orang layak dengan menggunakan aplikasi EAL yaitu keadilan secara ekonomi.
\end{abstract}

\section{A. Lingkup kriminologi}

Kriminologi berasal dari kata Crimen yang berarti kejahatan atau Penjahat, dan Logos yang berarti pengetahuan. Dari kata- kata tersebut Kriminologi berarti pengetahuan yang mempelajari tentang kejahatan. Kriminologi mempunyai dua cabang ilmu pengetahuan yaitu:

1. Penologi (Peno = hukuman/ punish dan Logos $=$ pengetahuan) yaitu ilmu yang mempelajari tentang hukuman atau penghukuman orang.

2. Viktimologi (Victim $=$ korban dan Logos = Pengetahuan) ilmu yang mempelajari tentang korban kejahatan. ${ }^{1}$

Penologi secara umum dapat disimpulkan sebagai bagian dari ilmu pengetahuan Kriminologi, yang mempelajari dasar - dasar pelaksanaan pemberian hukuman dengan perkembangan sistem dan tujuannya, manajemen kepenjaraan dengan unit-unit lembaganya. ${ }^{2}$

Paradigma Viktimologi mulai diperhatikan orang sejak Perserikatan Bangsa - Bangsa menghasilkan deklarasi 11 Desember 1985: "Declaration Of Basic Principles Of Justice

\footnotetext{
${ }^{1}$ A.Sanusi Has; Dasar- dasar Penologi; Rasanta, Jakarta; hlm.vii

${ }^{2}$ Ibid;
} 
for Victims of Crime and Abuse Of Power". ${ }^{3}$ Dalam hal ini pemahaman tentang Viktimologi ternyata sangat berkaitan dengan dunia hukum Pidana yang bertalian dengan kejahatan yang dilakukan oleh Korporasi, karena dari sini sangat jelas terlihat adanya Pelaku dan Korbannya. Jadi dengan demikian dapat dikatakan bahwa Paradigma Viktimologi tidak hanya bertalian dengan kejahatan dalam arti klasik saja, akan tetapi juga menyangkut perbuatan lain diluar bidang hukum pidana, misalnya "Abuse of Power" atau korban pencemaran lingkungan dan lainnya. ${ }^{4}$

Sutherland dan Cressey berpendapat bahwa :

"Criminology is the body of knowledge regarding crime as a social phenomenon". ${ }^{5}$

Hal ini dimaksudkan bahwa kriminologi merupakan sebuah pengetahuan yang berkaitan dengan fenomena sosial dalam hal proses pembentukan hukum, pelanggaran hukum, dan reaksi masyarakat terhadap para pelanggar hukum, maka pengertian kriminologi dapat dirinci sebagai Proses pembentukan hukum, Pelanggaran hukum, dan reaksi terhadap para pelanggar hukum.

Melihat adanya cabang ilmu kriminologi tersebut kemudian pemahaman tentang kriminologi dapat digolongkan dalam dua pemahaman yaitu :

${ }^{3}$ Karya Para Pakar Hukum; Bunga Rampai Viktimisasi; Eresco Anggota IKAPI; Abndung, 1995hln, v

${ }^{4}$ Ibid.

${ }^{5}$ E.H.Sutherland dan Donald R. Cressey; Principles Of Criminology, sixth Edition, Lippincott Company, New York; 1960, hlm. 3
1. Kriminologi dalam arti sempit yaitu ilmu yang mempelajari dan membahas hanya masalah kejahatan saja,

2. Kriminologi dalam arti luas yaitu ilmu yang membahas masalah kejahatan, berikut teknologi, metode dan prevensi dari kejahatan yang bersifat punitif.

Dalam mempelajari masalah kejahatan Hermann Mannhein mengemukakan ada tiga pendekatan:

(1). Pendekatan Deskriptif;

Pedekatan Sebab Akibat; Pendekatan secara Normatif. ${ }^{6}$

1. Pendekatan Deskriptif, dimaksudkan adalah suatu pendekatan dengan cara melakukan observasi dan pengumpulan data yang berkaitan dengan fakta - fakta tentang kejahatan atau pelaku kejahatan seperti, Bentuk tingkah laku kriminal; Bagaimana kejahatan dilakukan; Frekuensi kejahatan pada waktu dan tempat yang berbeda; Ciri-ciri pelaku kejahatan seperti usia, kelamin, suku; Perkembangan karir pelaku kejahatan.

Pendekatan deskriptif ini dikenal juga dengan nama Fenomenologi atau Simtomatologi. Dalam hal ini Hermann Mannhein menegaskan adanya beberapa syarat yang harus dipenuhi bila menggunakan pendekatan Deskriptif yaitu, (1). Pengumpulan fakta tidak dapat dilakukan secara random, karena

6 Hermann Mannheim; Comparative Criminology; Houghton Mifflin Company; Boston, 1965; hlm 3-12; (Dikutip dari buku Made Darma Weda; Kriminologi; Raja Grafindo Persada; Jakarta, 1996, hlm. 2) 
itu fakta yang diperoleh harus secara selektif; (2). Harus dilakukan penafsiran, evaluasi dan memberikan pengertian secara umum terhadap fakta-fakta yang diperoleh. Karena tanpa dilakukan penafsiran, evaluasi dan memberi pengertian secara umum, maka fakta-fakta tersebut tidak akan mempunyai arti.

2. Pendekatan Sebab Akibat, bahwa pemahaman terhadap kejahatan dapat dilakukan melalui pendekatan sebab akibat karena fakta-fakta yang terdapat dalam masyarakat dapat ditafsirkan untuk mengetahui sebab musabab kejahatan, baik dalam kasuskasus yang bersifat individual maupun yang bersifat umum. Hubungan sebab akibat dalam Kriminologi berbeda dengan hubungan sebab akibat yang terdapat dalam hukum Pidana.

Dalam hukum Pidana, agar suatu perkara dapat dilakukan penuntutan, harus dibuktikan dulu adanya hubungan sebab akibat antara suatu perbuatan dengan akibat yang dilarang. Dalam kriminologi hubungan sebab akibat dicari setelah hubungan sebab akibat dalam hukum pidana terbukti. Jadi lebih jelasnya adalah bila hubungan kausal secara pidana telah diketahui maka hubungan sebab akibat dalam kriminologi dapat dicari, yaitu dengan mencari jawaban atas pertanyaan mengapa orang tersebut melakukan kejahatan. Usaha untuk mengetahui kejahatan dengan menggunakan pendekatan sebab akibat ini dikatakan sebagai Etiologi kriminil (Etiology of Crime).

3. Pendekatan Secara Normatif, dalam pendekatan ini ada beberapa pendapat yang berbeda tentang kriminologi yaitu apakah kriminologi merupakan ilmu yang bersifat normatif atau bersifat non-normatif.

H. Bianchi menyatakan bila kejahatan itu merupakan konsep yuridis, berarti merupakan dorongan bagi kriminologi untuk mempelajari norma- norma. Oleh karena itu kriminologi merupakan disiplin yang normatif. Pendapat dari Herman Mannhein adalah kriminologi yang bersifat faktual (a factual discipline). ${ }^{7}$

Pandangan yang sempit yang mengartikan kejahatan dalam pengertian yuridis saja, dianut oleh Vouin-Leaute. Pendapatnya adalah semua perbuatan yang anti sosial dilarang oleh undang- undang, dan dirumuskan sebagai kejahatan oleh undang- undang. Selanjutnya ada kelompok yang berpendapat kriminologi dalam arti yang luas adalah kriminologi tidak hanya mempelajari perilaku yang bertentangan dengan norma-norma yang ada, tetapi hal lainnya yang tidak diatur dalam hukum pidana.

Sutherland dan Cressey mengemukakan pendapatnya yaitu ada 7 (tujuh) syarat untuk perbuatan dikategorikan sebagai kejahatan: ${ }^{8}$

\footnotetext{
${ }^{7}$ Made Darma Weda; Kriminologi; Raja Grafindo Persada; Jakarta, 1996, hlm. 5

8 Op.cit: E.H.Sutherland dan Donald R. Cressey; hlm. 12.
} 
a) Sebelum suatu perbuatan disebut sebagai kejhatan harus terdapat akibat-akibat tertentu yang nyata, yang merupakan kerugian.

b) Kerugian yang ditimbulkan harus merupakan kerugian yang dilarang oleh undang- undang, dan secara jelas tercantum dalam hukum pidana.

c) Harus ada perbuatan pembiaran terjadinya perbuatan yang menimbulkan kerugian tersebut.

d) Dalam melakukan perbuatan tersebut harus terdapat maksud jahat (mens rea),

e) Harus ada hubungan antara perilaku dan "mens rea",

f) Harus ada hubungan kausal antara kerugian yang dilarang undang undang dengan perbuatan yang dilakukan atas kehendak sendiri (tanpa unsur paksaan),

g) Harus ada pidana terhadap perbutan tersebut yang ditetapkan oleh undang- undang.

Secara keseluruhan jelas apa yang dimaksudkan diatas adalah merupakan pengertian kejahatan dalam arti yuridis. Apapun yang diperdebatkan tentang kriminologi, yang jelas kriminologi merupakan ilmu yang bukan saja sebagai pembantu hukum pidana tetapi lebih tepat lagi kriminologi dikatakan sebagai "Meta science" seperti yang dikemukakan oleh Bianchi yaitu ilmu yang memiliki ruang lingkup yang lebih luas dimana pengertiannya dapat digunakan untuk memperjelas konsepsi-konsepsi dan masalahmasalah yang terdapat dalam hukum pidana. Dengan demikian "meta science" bukan merupakan pelengkap hukum pidana. ${ }^{9}$

\section{B. Economic Analysis of Law dalam Teori dan Penjelasan Umum}

Memperhatikan komentar beberapa pakar yang berpendapat tentang "Economic Analysis of Law" pada umumnya menjelaskan bahwa era globalisasi dunia telah membawa dapak di semua lini kehidupan masyarakat termasuk didalamnya adalah dunia ilmu Ekonomi dan ilmu Hukum. Dalam hal ini ilmu hukum dan ilmu ekonomi masing - masing mempunyai tuntutan yang berbeda, namun dalam perkembangan selanjutnya kedua disiplin ilmu ini menjadi saling bergantung untuk menganalisa pemasalahanpermasalahan yang berkembang di masyarakat.

Sinergitas ilmu hukum dan ilmu ekonomi dapat dijelaskan bahwa kedua bidang ilmu ini sama-sama menjelaskan tentang perilaku manusia dimana ilmu hukum secara luas mengatur tentang perilaku manusia sedangkan ilmu ekonomi mempelajari perilaku manusia dalam memenuhi kebutuhannya, maka kedua ilmu ini memiliki korelasi (interdependen) untuk saling mendukung.

Hukum adalah "perintah" untuk itu Hans Kelsen menambahkan bahwa: "hukum adalah suatu perintah bersifat memaksa terhadap perilaku manusia, sekaligus merupakan kaidah primer yang menetapkan sanksi-sanksi". Jadi pada pokoknya hukum berisi perintah dan larangan dan ditegakkan dengan sanksi yang memaksa, namun demikian ada kalanya hukum juga

\footnotetext{
${ }^{9}$ Op.cit Made Darma Weda; hlm. 9
} 
berisi pembolehan atau pengecualian tertentu. ${ }^{10}$

Economic Analysis of Law ada menjelaskan tentang perluasan dimensi hukum melalui kajiannya, dalam hal ini diperjelas bagaimana sesungguhnya secara ke-ilmuan hubungan hukum dan ekonomi tidak terpisahkan, karena mereka saling melengkapi dan mengisi kekosongan masing - masing, kemudian ditawarkan jalan keluar terhadap permasalahan hukum. Dalam konteks yang lebih luas Economic Analysis Of Law adalah melengkapi ajaran keadilan melalui konsepsi keadilan ekonomi. ${ }^{11}$

Kuatnya tuntutan arus globalisasi telah membuat perdagangan memiliki kaitan erat dengan hukum, karena kedudukan hukum sangat penting guna mengatur perilaku manusia sebagai pelaku ekonomi dalam melakukan perbuatan hukum. Manusia sebagai pelaku ekonomi, juga sebagai subyek hukum diharapkan tidak menghilangkan keberadaan hukum walaupun didasari oleh alasan-alasan dan pertimbangan ekonomi. Untuk itu economic analysis of law lebih tepat dipahami sebagai analisa ke-ekonomian tentang hukum, bukan mentah-mentah diartikan sebagai analisis ekonomi (economic analysis), tentang hukum (of law). Sebab permasalahan hukum tetap sebagai subyek yang dikonstelasikan dengan konsep - konsep dasar ekonomi, alasan-alasan dan

${ }^{10}$ Hans Kelsen; Teori Hukum Murni, dasarDasar Ilmu Hukum Normatif:Nusa Media, bandung, 2014; hlm. 48

${ }^{11}$ Fajar Sugianto; Economic Analysis Of Law, Seri Analisis Ke-ekonomian tentang Hukum; Kencana Prenada media; Jakarta; 2013; hlm.ix pertimbangan ekonomis. Selain merepresentasikan komponen keekonomian dan sifat ke-ekonomian dalam analisis hukum, tujuan utamanya adalah untuk dapat mendudukkan hakikat persoalan hukum, sehingga keluasan analisis hukum (bukan analisis ekonomi) menjadi lebih terjabarkan. ${ }^{12}$

Konsep pemikiran analisis keekonomian tentang hukum diawali dari pondasi untilitarianisme yang dibangun oleh Jeremy Bentham yaitu menekankan prinsip kemanfaatan sebagai doktrin ilmu hukum. Dalam hal ini menurutnya hukum barulah dapat diakui sebagai hukum apabila dapat memberikan kemanfaatan yang sebesar-besarnya kepada orang banyak. Teori Felcific Calculus (Quantitative of Social Pleasures and Pains) dikembangkan dengan asumsi dasar: ${ }^{13}$

1. Kebahagian setiap individu meningkat pada saat dimana jumlah total kepuasannya lebih besar daripada kesedihannya;

2. Keuntungan atau benefit secara umum dari suatu komunitas terdiri dari seluruh benefit sekelompok individu;

3. Kebahagiaan dari suatu kumunitas dapat ditingkatkan apabila jumlah total seluruh kepuasan individuindividu dalam komunitas tersebut lebih besar skalanya daripada kesedihan atau kesengsaraan mereka.

\footnotetext{
${ }^{12}$ Ibid; hlm.7

13 Jurisprudence, $4^{\text {th }}$ edition, Routledge , Cavendish Lawcard Series, 2006; hlm 85 (Dikutip dari Fajar Sugianto Economic Analysis Of Law, Seri Analisis Ke-ekonomian tentang Hukum; Kencana Prenada media; Jakarta; 2013; hlm43)
} 
Oleh karena naluri dan kemampuan setiap individu sebagai manusia untuk merasakan kepedihan, kesediahan, kesengsaraan atau kebahagiaan / kepuasan, maka nurani perasaan manusia ini yang menjadi tolok ukur (total Utility) Bentham untuk parameter kepuasan atau kekecewaan. Berdasarkan kerangka pemikiran Bentham ini Posner ${ }^{14}$ menyampaikan konsepsi analisis ke-ekonomian tentang hukum berawalmula dari pengertian dasar bahwa pada dasarnya manusia sebagai makluk hidup adalah "homo economicus" yang artinya dalam megambil tindakan untuk pemenuhan kebutuhan ekonominya, mereka mengedepankan nilai ekonomis dengan alasan dan pertimbangan ekonomis. ${ }^{15}$

Selanjutnya Posner menjelaskan bahwa analisa ke-ekonomian tentang hukum dapat dijadikan suatu pendekatan untuk menjawab permasalahan hukum dengan mengutarakan definisi berbeda dari asumsi-asumsi hukum yang berbeda juga guna mendapat gambaran tentang kepuasan (satisfaction) dan peningkatan kebahagiaan (maximization of happiness). Pendekatan ini erat kaitannya dengan keadilan di dalam hukum. Untuk melakukannya maka hukum dijadikan economic tools untuk mencapai maximization of happiness. $^{16} \quad$ Pendekatan dengan

${ }^{14}$ Richard Allen Posner lahir pada tanggal 11 Januari tahun 1939. Ia adalah seorang ahli hukum, teori hukum, dan ekonom yang saat ini menjadi hakim di United States Court of Appeals for the Seventh Circuit di Chicago. Ia juga merupakan seorang pengajar senior di University of Chicago Law School.

${ }^{15}$ Ibid, Fajar Sugianto; hlm. 45.

${ }^{16}$ Bushan J, Komadar, Journal: The Raise and Fall of a Major Finalcial Instrument, Univer sity of Westminster, 2007; hlm. 1((Dikutip dari Fajar penggunaan analisis ini harus disusun dengan pertimbangan - pertimbangan ekonomi dengan tidak menghilangkan unsur keadilan, sehingga keadilan dapat menjadi economic standard yang didasari oleh tiga elemen dasar, yaitu nilai (value), kegunaan (utility), dan efisiensi (efficiency) yang didasari oleh rasionalitas manusia. ${ }^{17}$

Berdasarkan konsep dasar analisa keekonomian tentang hukum yang dikembangkan oleh Posner kemudian dikenal dengan the economic conception of justice, dengan simpulan bahwa hukum diciptakan dan diaplikasikan untuk tujuan utama meningkatkan kepentingan umum seluas-luasnya (maximizing overall social utility). Dengan demikian The economic conception of justice, menjadi acuan untuk menilai sampai sejauh mana dampak pemberlakuan suatu ketentuan hukum atau peraturan perundang - undangan kepada masyarakat luas. Dari sini dapat lebih mudah diketahui reaksi masyarakat dan kemanfaatan hukum atau peraturan perundang - undangan tersebut.

Posner dalam kerangka analisa hukum yang dikembangkan melalui konsep analisa ke-ekonomian tentang hukum berpendat bahwa orang akan menaati ketentuan hukum apabila ia memperkirakan dapat memperoleh keuntungan lebih besar daripada melanggarnya, demikian juga sebaliknya. Maka berdasarkan alur berfikir posner, ternyata analisa ke-

Sugianto Economic Analysis Of Law, Seri Analisis Keekonomian tentang Hukum; Kencana Prenada media; Jakarta; 2013; hlm45).

${ }_{17}$ Richard A. Posner, Economic Analysis Of Law, seventh edition, NewYork: Aspen Publishers, 2007, hlm. 3, 249-256. 
ekonomian hukum merupakan analisis hukum yang mengaplikasikan atau menggunakan konsep-konsep ekonomi untuk menjelaskan akibatakibat hukum, mengevaluasi, atau mengestimasi sifat dasar, kemampuan atau kualitas suatu produk hukum yang efisien ekonomis, sehingga dapat diprediksikan produk hukum apa yang patut untuk diberlakukan.

\section{Penerapan Economic Analysis Of Law Pada Pemidanaan}

Dalam ilmu Kriminologi Sutherland dan Cressey telah menjelaskan bahwa untuk karegori perbuatan yang dilakukan oleh seseorang sebagai bentuk kejahatan, ternyata bahwa bentuk perbuatan itu dapat disebut sebagai kejahatan harus terdapat akibat-akibat tertentu yang nyata, yang merupakan kerugian bagi orang lain atau masyarakat lainnya. Kerugian yang ditimbulkan itu harus merupakan kerugian yang dilarang oleh undang-undang, dan secara jelas tercantum dalam hukum pidana. Dalam melakukan perbuatan tersebut harus terdapat maksud jahat (mens rea) dari pelakunya, selanjutnya harus ada perbuatan perbuatan pembiaran terjadinya perbuatan yang menimbulkan kerugian tersebut.

Konsep pilihan rasional melalui dasar analisis ke-ekonomian tentang hukum dimulai dari asumsi dasar bahwa pada hakikatnya manusia adalah makhluk rasional. Dengan adanya rasionalitas yang melekat pada masing - masing individu, manusia diberi pilihan untuk memilih sebagaimana diyakini akan memberikan hasil yang terbaik yang di inginkannya. Mengingat kepuasan manusia sifatnya tidak terbatas dan manusia tidak pernah puas dengan apa yang didapatnya sehingga manusia didorong untuk mengambil keputusan terbaik dari pilihan-pilihan yang ada, baik yang bersifat individu maupun kelompok. Sebagai makhluk rasional, pilihan yang dipilihnya adalah berdasarkan untung rugi, kelebihan kekurangan, kemampuan keterbatasan, sesuai dengan tingkat rasionalitasnya, dan juga mencari alternatif terbaik atas pilihannya. ${ }^{18}$

Economic Analysis of Law, terhadap pemidanaan menjelaskan bahwa pada pemidanaan ada terdapat empat para meter untuk menjustifikasi dan mendeterminasi pemidanaan, salah satunya adalah "ex ante". Hal ini merupakan ancaman pidana kepada orang-orang yang belum secara de fakto melakukan tindak pidana, tetapi memiliki niatan, rencana, bahkan usaha melakukan tindak pidana. Dalam perundang-undangan hukum pidana perbuatan "ex ante" ini dikategorikan sebagai tindak pidana ${ }^{19}$ sehingga memenuhi syarat untuk mengkualifikasi seseorang menjadi pelaku tindak pidana. Sebaliknya, "ex post" menekankan pemidanaan kepada orang-orang yang sudah secara de facto melakukan tindak pidana sehingga memenuhi syarat untuk ditetapkan menjadi pelaku tindak pidana.

Analisa Ke-ekonomian Hukum juga menawarkan tiga pendekatan yang membantu memformulasikan penghukuman optimal yaitu: ${ }^{20}$

\footnotetext{
${ }^{18}$ Op.Cit. Ibid, Fajar Sugianto; hlm. 50

${ }^{19}$ Fajar Sugianto; Economic Analysis Of Law, Seri Analisis Ke-ekonomian tentang Hukum; Kencana Prenada media; Jakarta; 2013; hlm. 93.

${ }^{20} \mathrm{Ibid}, \mathrm{hlm} .94$
} 
1. Semua sanksi paling tidak harus sama dengan keuntungan bagi pelaku (sanctions equal to wrongdoer's gains). ${ }^{21}$ Dalam hal ini mengukur keuntungan bagi pelaku pada dasarnya tidak dapat diukur, namun hal ini dapat dilihat dari kerugian atau cidera (kerusakan) dari pihak korbannya. Asumsi yang digambarkan adalah kerugian atau cidera/kerusakan dari pihak korban lebih besar dari keuntungan si pelaku.

2. Esensi penghukuman sebagai penerapan act-based rules atau harm-based rules. Harm-based rules memiliki esensi yang sama dengan penghukuman optimal berdasarkan kerugian korban. Dalam hal ini penjeraan akan dianggap lebih efisien untuk mengurangi pengulangan tindak pidana, karena pelaku menyadari bahwa penghukuman atas tindak pidana yang dilakukannya lebih berat dari yang diperkirakan keuntungannya.

3. Menghitung penjeraan marginal (Marginal Deterence)

a. Pada hakikatnya Marginal Deterence merupakan bentuk pemidanaan sesuai dengan tingkat tindak pidana, mulai dari yang ringan hingga terberat;

b. Pelaku memiliki pilihan untuk melakukan tindak pidana dengan tujuan yang sama, namun menurut pelaku penghukumannya lebih ringan

${ }^{21}$ Steven Shavell, Foundations Of Economic Analysis Of Law, London: The Belknap Press of Harvard University Press, 2004; hlm. 477. (di kutip dari buku Fajar Sugianto; Economic Analysis Of Law; hlm. 93).
Melalui kerangka teoretik analisis keekonomian tentang hukum, Posner memaparkan bahwa keberadaan hukum di tengah-tengah kehidupan ini, pada dasarnya sebagai perangkat peraturan atau sanksi-sanksi yang bertujuan untuk mengatur perilaku manusia yang pada hakikatnya berkeinginan untuk meningkatkan kepuasannya, sebagaimana hal ini menjadi bagian dari ekonomi. Hukum karena itu dibuat dan digunakan untuk tujuan meningkatkan kepentingan umum seluas-luasnya, karena dari sudut pandang ekonomi, produk hukum yang mampu mengakomodir berarti produk yang progresif, berlaku efektif, bekerja efisien, dan responsif terhadap perkembangan dan tuntutan jaman.

\section{Analysis Economic Of Law Dalam Kejahatan Dan Hukuman}

Salah satu asas dalam hukum pidana adalah Asas Legalitas, yaitu tidak ada suatu perbuatan dapat dipidana kecuali atas kekuatan aturan pidana dalam Peraturan PerundangUndangan yang telah ada sebelum perbuatan itu dilakukan (Pasal 1 Ayat (1) KUHP). Jika sesudah perbuatan dilakukan ada perubahan dalam Peraturan Perundang-Undangan, maka yang dipakai adalah aturan yang paling ringan sanksinya bagi terdakwa (Pasal 1 Ayat (2) KUHP).

Pengertian tindak pidana yang dimuat di dalam Kitab Undang-Undang Hukum Pidana (KUHP) oleh pembentuk undang-undang sering disebut dengan strafbaarfeit. Maka terhadap maksud dan tujuan mengenai strafbaarfeit tersebut sering dipergunakan oleh pakar hukum 
pidana dengan istilah tindak pidana, perbuatan pidana, peristiwa pidana, serta delik. ${ }^{22}$

Unsur-unsur tindak pidana, unsur formal meliputi :

1. Perbuatan manusia, yaitu perbuatan dalam arti luas, artinya perbuatan dan dilakukan oleh manusia.

2. Melanggar peraturan pidana, dalam arti bahwa sesuatu akan dihukum apabila sudah ada peraturan pidana sebelumnya yang telah mengatur perbuatan tersebut, jadi hakim tidak dapat menuduh suatu kejahatan yang telah dilakukan dengan suatu peraturan pidana, maka tidak ada tindak pidana.

3. Diancam dengan hukuman, hal ini bermaksud bahwa KUHP mengatur tentang hukuman yang berbeda berdasarkan tindak pidana yang telah dilakukan.

4. Dilakukan oleh orang yang bersalah, dimana unsur-unsur kesalahan yaitu harus ada kehendak, keinginan atau kemauan dari orang yang melakukan tindak pidana serta orang tersebut berbuat sesuatu dengan sengaja, mengetahui dan sadar sebelumnya terhadap akibat perbuatan, kesalahan dalam arti sempit dapat diartikan kesalahan yang disebabkan karena si pembuat kurang memperhatikan akibat yang tidak dikehendaki oleh undang-undang.

5. Pertanggungjawaban yang menentukan bahwa orang yang tidak sehat ingatannya tidak

${ }^{22}$ Sudarto, Hukum Pidana dan Perkembangan Masyarakat, Bandung: Sinar Baru, 1983, hlm 34 dapat diminta pertanggung jawabannya. Dasar dari pertanggungjawaban seseorang terletak dalam keadaan jiwanya.

Hukum pidana adalah semua dasardasar dan aturan - aturan yang dianut oleh suatu negara dalam menyelenggarakan ketertiban hukum (rechts order) dengan melarang apa yang bertentangan dengan hukum dan mengenakan suatu nestapa kepada yang melanggar laranganlarangan tersebut selanjutnya mengadakan dasar-dasar atau aturanaturan untuk, (1). Menentukan perbuatan-perbuatan mana yang tidak boleh dilakukan, yang dilarang, dengan disertai ancaman atau sangsi berupa pidana tertentu bagi barang siapa melanggar larangan tersebut; (2). Menentukan kapan dan dalam hal-hal apa kepada mereka yang telah melanggar larangan-larangan itu dapat dikenakan atau dijatuhi pidana sebagaimana yang telah diancamkan; (3). Menentukan dengan cara bagaimana pengenaan pidana itu dapat dilaksanakan apabila ada orang yang disangka telah melanggar larangan tersebut (Penghukuman orang). ${ }^{23}$

Manusia pada dasarnya tidak pernah putus asa menghadapi kejahatan, dan sepanjang sejarah ternyata belum pernah ditemukan suatu cara yang paling ampuh untuk mengurangi angka kejahatan. Bahkan sampai dengan kondisi saat ini kejahatan berkembang sejalan dengan berkembangnya teknologi. Maka terbentuk kejahatan baru dengan istilah Kejahatan Kontemporer

23 Moelyatno, Asas-Asas Hukum Pidana, Rineka Cipta, Jakarta, 2008, hlm 9 
dimana pelakunya adalah oknum atau orang khusus, bahkan bisa juga organisasi dan lembaga formal tertentu dengan alat yang digunakan umumnya didukung oleh teknologi tinggi, oleh karena itu korbannya juga tak terhingga dalam arti sulit dihitung.

Dalam kongres PBB ke-empat pada tahun1970 yang diselenggarakan di Kyoto tentang pencegahan kejahatan dan pembinaan pelaku kejahatan (Fourth United Nations Congress on The Prevention of Crime and Treatment Of Offenders) tidak dapat menetapkan dengan pasti hubungan antara kejahatan dan perkembangan (development), sehingga menurut kongres tidak beralasan untuk mengatakan bahwa perkembangan masyarakat akan mencegah terjadinya kejahatan atau sebaliknya bahwa perkembangan itu menyebabkan kejahatan. Akan tetapi kongres mengakui beberapa aspek penting dari perkembangan masyarakat yang dianggap potensi sebagai kriminogen yang berarti mempunyai kemungkinan untuk menimbulkan kejahatan, seperti urbanisasi, pertambahan penduduk, industrialisasi, perubahan sosial dan perubahan teknologi. ${ }^{24}$

Untuk menjawab pertanyaan mengapa orang melakukan kejahatan, pada dasarnya ada beberapa mazhab dalam ilmu Kriminologi yang dapat menjelaskan hal tersebut, salah satunya adalah Mazhab Klasik. Aliran ini ada di Inggris pada pertengahan

${ }^{24}$ Sudarto; Pengaruh Perkembangan Masyarakat Terhadap Hukum Pidana; Kertas kerja dalam Simposium Pengaruh Kebudayaan /Agama Terhadap Hukum Pidana- Badan Pembinaan Hukum Nasional; Biana Cipta 1975 , hlm. 31 (dikutip dari Made darma Weda; hlm.20) abad ke 19 dan tersebar di Eropa dan Amerika. Mazhab ini didasarkan pada "Psikologi Hedonistik", dalam arti setiap perbuatannya manusia didasarkan atas pertimbangan rasa senang dan rasa tidak senang. Setiap manusia berhak memilih mana yang baik dan mana yang buruk, perbuatan mana yang mendatangkan kesenangan dan mana yang tidak. Dengan demikian setiap perbuatan yang dilakukan adalah perbuatan yang mendatangkan kesenangan, dalam arti orang melakukan kejahatan karena perbuatan tersebut mendatangkan kesenangan bagi dirinya. ${ }^{25}$

Beccaria (1764) menerapkan prinsip ini sebagai doktrin dalam Penologi, menurutnya setiap orang yang melanggar hukum telah memperhitungkan kesenangan dan rasa sakit yang diperoleh dari perbuatan tersebut. Dengan demikian pidana berat sekalipun sebagai resiko dari perbuatannya adalah merupakan kesenangan yang akan diperolehnya. ${ }^{26} \mathrm{Hal}$ ini sejalan dengan prinsip "Konsep Pilihan Rasional" melalui dasar analisis ke-ekonomian tentang hukum yang dimulai dari asumsi dasar bahwa pada hakikatnya manusia adalah makhluk rasional.

Dengan adanya rasionalitas yang melekat pada masing-masing individu, manusia diberi pilihan untuk memilih sebagaimana diyakini akan memberikan hasil yang terbaik yang di inginkannya. Sebagai makhluk rasional, pilihan yang dipilihnya adalah berdasarkan untung rugi,

\footnotetext{
${ }^{25}$ Made darma Weda; Kriminologi; Raja Grafindo Persada; Jakarta, 1996, hlm. 14

${ }^{26}$ Op.Cit E.H.Sutherland dan Donald R. Cressey; hlm. 52
} 
kelebihan kekurangan, kemampuan keterbatasan, sesuai dengan tingkat rasionalitasnya, dan juga mencari alternatif terbaik atas pilihannya sekalipun itu adalah bentuk kejahatan atau pernbuatan yang merugikan orang lain.

Untuk menanggulangi kejahatan pada prinsipnya ada dua metode yaitu: $:^{27}$

1. Pencegahan secara umum (general prevention) dengan program yang umum dan luas untuk menghindarkan orang - orang supaya tidak melakukan suatu perbuatan yang melanggar hukum. Dalam hal ini kemungkinan akan tergantung pada politik suatu negara dalam hal pekembangan kesejahteraan rakyatnya.

2. Pencegahan khusus yaitu suatu usaha untuk mengurangi angka kejahatan dengan hukuman dan berusaha membina pelaku kejahatan.

Pada dasarnya manusia menyadari bahwa perbuatan jahat tidak mudah dapat dihilangkan atau dimusnahkan, karena akan lahir lagi bentuk kejahatan baru ditempat yang baru. Oleh karena itu salah satu upaya manusia untuk menekan angka kaejahatan adalah melakukan sesuatu terhadap pelaku kejahatan agar tidak berbuat jahat lagi dengan cara penerapan hukuman dengan efek jera.

Dalam ajaran Islam disebutkan perlunya pemberian hukuman ialah: "Suatu hukuman yang diancam kepada pembuat pidana (dader) ialah agar supaya orang banyak tidak

${ }^{27}$ A.Sanusi Has; Dasar-dasar Penologi; Rasanta, Jakarta; hlm.22. melakukan suatu jarima, sebab larangan atau perintah tidak cukup. Meskipun hukuman itu sendiri bukanlah merupakan suatu kebaikan, bahkan suatu pengrusakan bagi sipembuat pidana itu sendiri, akan tetapi meskipun demikian hukuman tersebut sangat diperlukan, oleh karena hal itu dapat membawa keuntungan bagi masyarakat." Bahwa agama Islam mencegah dilakukannya sesuatu yang terlarang dengan cara memperingatkan hukuman pidana yang dijatuhkan oleh Allah kelak dalam bentuk dan versi yang dapat membangkitkan rasa takut yang cukup besar dalam jiwa seseorang mukmin. Disamping itu agama Islam menentukan pula perbuatanperbuatan pidana atau hukuman dunia, sehingga oleh karenanya diharapkan oleh agama Islam kedua macam hukuman itu dapat hendaknya saling bekerjasama dalam menumpas dan mencegah terjadinya suatu kejahatan/ pelanggaran, dengan cara menggunakan pencegahan secara agama dan kekuasaan, yakni dengan ancaman hukuman. ${ }^{28}$

Alasan Negara melaksanakan pemberian hukuman adalah tergantung atau terpengaruh pada filsafat kehidupan yang dianut oleh negara tersebut. Meuwissen tentang "Pengembanan Hukum, Ilmu Hukum, Teori Hukum, dan Filsafat Hukum" ada menjelaskan atas dasar apa penguasa mempunyai hak (berkewajiban) menjatuhkan

${ }^{28}$ Abdulgani Karim, Pengaruh Agama Islam Terhadap Hukum Pidana Nasional, Kertas Kerja dalam Simposium Pengaruh kebudayaan/ Agama Terhadap Hukum Pidana - Badan Pembinaan Hukum Nasional; Binacipta 1975, hlm. 60 (dikutup dari buku A.Sanusi Has; Dasar- dasar Penologi; Rasanta, Jakarta; hlm.25). 
hukuman kepada orang, yaitu (1). Mengajukan bahwa penjahat dapat dan harus dididik dengan bantuan hukuman (teori perbaikan, Verbeteringstheorie); (2). Yang dinamakan ajaran prevensi bertolak dari pandangan bahwa melalui hukuman maka masyarakat terlindungi dari kerugian yang lebih jauh (lebih banyak). Selain itu juga penjahat dapat dicegah melakukan lebih banyak peristiwa pidana. Akhirnya dalam teori pembalasan (Vergeldingstheorie) hukuman itu dilandaskan pada respek yang wajib di berikan pada pribadi manusia. Pada dasarnya menghukum adalah dengan sengaja memberikan penderitaan kepada orang. ${ }^{29}$

Pembicaraan tentang penghukuman umumnya didahului dengan tanggapan mengenai siapa yang berhak menghukum dan tujuan pemberian hukuman. Pada dasarnya hakekat dari penghukuman adalah memberi suatu rasa derita yang dikenakan pada si pelaku perbuatan tercela, dalam arti pengertian punishment secara luas sebagaimana pengenaan tindakan yang tidak mengenakkan karena kehilangan hak kemerdekaannya. Jadi prinsip penghukuman adalah: "Suatu bentuk pernyataan dari instink manusia untuk mengadakan pembalasan atau keinginan untuk mengadakan pembalasan dalam proses yang berlainan yaitu pemberian hukuman pada pelaku kejahatan. Hal itu dapat diuraikan sebagai berikut:

\footnotetext{
${ }^{29}$ Meuwissen; Pengembanan Hukum, Ilmu Hukum, Teori Hukum, dan Filsafat Hukum; Penerjemah; Prof.DR. B. Arief Sidharta, SH); Refika Aditama, Bandung; 2013; hlm. 101.
}

1. Hukuman dilakukan dengan dasar harus memajukan dan mendukung perbuatan atau tindakan mempertahankan tata tertib dalam masyarakat;

2. Hukuman harus dapat mencegah terjadinya perbuatan - perbuatan yang dapat menimbulkan kekacauan;

3. Negara harus mempertahankan tata tertib kemasyarakatan yang ada;

4. Negara harus mengembalikan ketentraman dalam masyarakat apabila ketentraman itu terganggu. ${ }^{30}$

Berdasarkan konsep dasar analisa keekonomian tentang hukum yang dikembangkan oleh Posner kemudian dikenal dengan the economic conception of justice, dengan simpulan bahwa hukum diciptakan dan diaplikasikan untuk tujuan utama meningkatkan kepentingan umum seluas-luasnya (maximizing overall social utility). Dengan demikian The economic conception of justice, menjadi acuan untuk menilai sampai sejauh mana dampak pemberlakuan suatu ketentuan hukum atau peraturan perundang - undangan kepada masyarakat luas. Dari sini dapat lebih mudah diketahui reaksi masyarakat dan kemanfaatan hukum atau peraturan perundang-undangan tersebut bagi masyarakat.

\section{E. Hukuman Mati berdasarkan Economic Analysis Of Law}

Di dalam sistem kepenjaraan, tujuan pemidanaan adalah penjeraan.

30 Sudjono D; The Control of Crime; Hukuman Dalam Perkembangan Hukuman Pidana; Transito, Bandung; 1974, hlm 7. 
Dengan demikian tujuan diadakannya penjara sebagai tempat menampung para pelaku tindak pidana dimaksudkan untuk membuat orang jera (regred) dan tidak lagi melakukan tindak pidana. Untuk itu peraturanperaturan dibuat keras, bahkan cenderung tidak manusiawi. ${ }^{31}$

Jenis pidana yang dijatuhkan oleh hakim pidana telah diatur dalam pasal 10 Kitab Undang-Undang Hukum Pidana (KUHP). Dalam pasal ini disebutkan jenis-jenis pidana yang dapat dijatuhkan terhadap terpidana atau pelaku tindak pidana adalah:

1. Pidana pokok, terdiri dari pidana mati, pidana penjara, pidana kurungan dan pidana denda.

2. Pidana tambahan, terdiri dari pencabutan hak-hak tertentu, perampasan barang-barang tertentu dan pengumuman keputusan hakim.

Adapun perubahan - perubahan sosial, ekonomi dan politik di Indonesia telah menimbulkan dasardasar yang melandasi isi, identitas, eksistensi serta struktur hukum nasional, adalah tugas dari penguasa negara untuk mempertahankan ketertiban hukum yang diwujudkan dengan hukum pidana, mengartikan bahwa penguasa negara mempunyai hak untuk memidana dan untuk membalas kejahatan. Hak penguasa untuk memidana mati adalah merupakan suatu akibat logis daripada haknya untuk membalas dengan pidana tersebut.

Barda Nawawi Arief dan Muladi menyatakan bahwa hubungan antara

${ }^{31}$ R.A Koesnoen; Politik Penjara Nasional; Sumur Bandung. penetapan sanksi pidana dan tujuan pemidanaan adalah titik penting dalam menentukan strategi perencanaan politik kriminal. Menentukan tujuan pemidanaan dapat menjadi landasan untuk menentukan cara, sarana atau tindakan yang akan digunakan. Kebijakan menetapkan sanksi pidana apa yang dianggap paling baik untuk mencapai tujuan, setidak-tidaknya mendekati tujuan, tidak dapat dilepaskan dari persoalan pemilihan berbagai alternatif sanksi. Masalah pemilihan berbagai alternatif untuk memperoleh pidana mana yang dianggap paling baik, paling tepat, paling patut paling berhasil atau efektif merupakan masalah yang tidak mudah. ${ }^{32}$

Hukuman mati diatur dalam beberapa undang-undang, diantaranya, Kitab Undang-undang Hukum Pidana (KUHP), Undang-undang Nomor 35 Tahun 2009 tentang Narkotika (UU Narkotika) dan Undang-undang Nomor 31 Tahun 1999 tentang Pemberantasan Tindak Pidana Korupsi sebagaimana diubah dengan Undang-Undang Nomor 20 Tahun 2001 (UU Pemberantasan Korupsi). Selain itu, Mahkamah Konstitusi juga pernah menguji penerapan hukuman mati terhadap UUD 1945 dan menyatakan bahwa "Pidana Mati" tidak bertentangan dengan semua undang-undang posif yang ada melalui putusan MK Nomor 23/PUU-V/2007- Jakarta.

Diluar KUHP juga tercantum pidana mati, seperti pada pasal 1 ayat (2) undang - undang No. 21 (Prp) 1959

${ }^{32}$ Zainal Abidin, Hukum Pidana,(Jakarta: Sinar Grafika,2005),hlm 6 
Menangulangi Kejahatan Dengan Aplikasi Economic Analysis Of Law

yang memperberat ancaman pidana delik ekonomi jika dapat menimbulkan kekacauan perekonomian dalam masyarakat, Undang - undang Pemberantasan Kegiatan Subversi (UU No 11 (PnPs) 1963, Undang-undang Tenaga Atom (UU No 31 tahun 1964), dan juga Undang-undang tentang Narkotika.

Sebagaimana telah dikemukakan diatas bahwa semua spekulasi pembenaran mengenai penerapan pidana mati, memang akhirnya telah menempatkan Indonesia sebagai salah satu negara yang paling banyak menjatuhkan vonis mati. Angka orang yang dihukum mati di Indonesia termasuk cukup tinggi setelah Cina, Iran, Irak, Arab Saudi dan Amerika Serikat, meskipun hukuman mati, baru terlihat kembali di Indonesia pada tahun $1982 .{ }^{33}$

Menurut Kepala Pusat Penerangan Hukum (Kapuspenkum) Kejaksaan Agung, bahwa semua teknis pelaksanaan hukuman mati di Indonesia sudah tercantum di dalam Undang-undang nomor 2 PNPS Tahun 1964 tentang Tata Cara Pelaksanaan Pidana Mati. Ini berarti pelaksanaan hukuman mati di Indonesia telah dilaksanakan secara manusiawi dengan menghargai harkat martabat yang di hukum maupun pelaksana hukuman mati tersebut.

Pendapat lain mengatakan bahwa hukuman mati adalah sebuah bentuk arogansi dari pihak berwenang, namun banyak peneliti telah menunjukkan bahwa hukuman mati

33

http://www.dw.com/id/statistikhukuman-mati-di-asia/a-16731798 diakses pada Februari 2016 tidak mencegah kejahatan

dibandingkan dengan bentuk

hukuman lain, tapi dalam hal ini pemerintah Indonesia yang mendukung hukuman mati untuk pelanggaran narkoba mempercayai bahwa jenis hukuman ini bisa mengurangi kejahatan. Seperti yang ditekankan oleh Presiden Joko Widodo beberapa kali, bahwa setidaknya ada 50 orang meninggal setiap hari di Indonesia karena penggunaan narkoba. ${ }^{34}$ Untuk itu hukuman mati diyakini menjadi cara efektif mengurangi dampak ini, dan untuk mencegah kaum muda terlibat dalam penggunaan dan penyalahgunaan obat. Dalam hal ini, ada keyakinan bahwa lebih baik 'membunuh' segelintir manusia, demi menyelamatkan lebih banyak nyawa.

Mengingatkan akan maraknya peredaran narkoba di Indonesia presiden menegaskan bahwa setelah Indonesia melaksanakan hukuman mati, maka Negara yang tidak sepaham boleh saja mengkritik pedas atau mengecam apa yang telah terjadi di Indonesia. Namun Indonesia memiliki prinsip dan sikap sendiri atas pelaksanaan pidana mati yang akan dilaksanakan lagi nanti.

Hukuman Mati bagi pelaku Extra Ordinary Crime /Kejahatan luar biasa pada dasar wajib diterapkan (penegakan) hukum luar biasa juga (Extraordinary Law), mengingat bahwa kejahatan luar biasa adalah merupakan kejahatan tak berprikemanusian atau melanggar Hak Asasi Manusia (HAM) dan

http://www.kompasiana.com/santarosa/extraordin ary-crime-extraordinary-law diakses pada Juli 2015. 
beberapa gambaran umum akan contoh tindak pidana yang digolongkan di dalamnya seperti teroris, korupsi, narkoba, dan lain-lain sebagainya.

Kejahatan luar biasa adalah suatu perbuatan yang dilakukan dengan maksud untuk menghilangkan hak asasi umat manusia lain, dan telah disepakati sacara internasional sebagai pelanggaran HAM berat yang berada dalam yurisdiksi International Criminal Court dan Statuta Roma, mendapatkan hukuman seberat-beratnya termasuk hukuman mati bagi pelaku kejahatan tersebut. Untuk Extraordinary Crime, internasional mengenal kejahatan genosida, kejahatan terhadap kemanusiaan, kejahatan perang, dan kejahatan agresi. Khususnya bagi Indonesia, tindak kejahatan korupsi dan narkoba yang kiranya kian merajalela di negeri ini maka kejahatan ini telah dimasukkan kedalam katergori Extraordinary Crime dan hal tersebut sudah dipahami secara umum. ${ }^{35}$

Sebagaimana zaman berubah dan tindakan yang dikategorikan Extraordinary Crime juga mengalami perubahan, maka kejahatan terorisme, korupsi, dan narkoba adalah jenisjenis tindak kejahatan baru yang mengancam bangsa dan negara Indonesia. Oleh karena itu Indonesia layak menerapkan hukum berat di negeri ini sebagaimana rasa "keadilan" secara ekonomi yaitu pidana mati.

Analisa ke-ekonomian tentang hukum dapat dijadikan suatu pendekatan untuk menjawab permasalahan penerapan hukuman mati di

${ }^{35} \mathrm{lbid}$;
Indonesia dengan mengutarakan definisi berbeda dari asumsi-asumsi hukum yang berbeda juga untuk mendapat gambaran tentang kepuasan (satisfaction) dan peningkatan kebahagiaan (maximization of happiness). Pendekatan ini erat kaaitannya dengan keadilan secara ekonomi di dalam hukum. Untuk melakukannya maka hukum dijadikan economic tools untuk mencapai maximization of happiness.

Pendekatan dengan penggunaan analisis ini harus disusun dengan pertimbangan-pertimbangan ekonomi dengan tidak menghilangkan unsur keadilan, sehingga keadilan dapat menjadi economic standard yang didasari oleh tiga elemne dasar, yaitu nilai (value), kegunaan (utility), dan efisiensi (efficiency) yang didasari oleh rasionalitas manusia, bahwa hukum diciptakan dan diaplikasikan untuk tujuan utama meningkatkan kepentingan umum seluas-luasnya (maximizing overall social utility). Dengan demikian The economic conception of justice, menjadi acuan untuk menilai sampai sejauh mana aspek pemberlakuan suatu ketentuan hukum atau peraturan perundangundangan kepada masyarakat luas. Dari sini dapat lebih mudah diketahui reaksi masyarakat dan kemanfaatan hukum atau peraturan perundangundangan pada penerapan hukuman mati.

\section{F. Kesimpulan}

Analisa ke-ekonomian terhadap hukum yang telah dibangun pada dasarnya dapat di aplikasikan sebagai filter efektivitas dan resposivitas terhdap regulasi ketentuan hukum 
yang nantinya akan melahirkan prinsip-prinsip hukum baru terutama dalam hal pengenaan atau penerapan hukuman bagi pelaku kejahatan, mengingat kerangka analisa hukum yang dikembangkan melalui konsep analisa ke-ekonomian tentang hukum berpendat bahwa orang akan menaati ketentuan hukum apabila ia memperkirakan dapat memperoleh keuntungan lebih besar daripada melanggarnya, demikian juga sebaliknya. Maka berdasarkan alur berfikir ini ternyata analisa keekonomian tentang hukum merupakan analisis hukum yang mengaplikasikan atau menggunakan konsep-konsep ekonomi untuk menjelaskan akibat-akibat hukum, mengevaluasi, atau mengestimasi sifat dasar, kemampuan atau kualitas suatu produk hukum yang efisien ekonomis, sehingga dapat diprediksikan produk hukum apa yang patut untuk diberlakukan.

Maraknya perilaku kriminal yang dilakukan oleh oknum, lembaga formal, organisasi formal di negara ini menunjukkan akan perlunya suatu kebijakan baru dibindang penghukuman orang mengingat mereka yang melakukan perbuatan jahat tersebut umumnya adalah orang dengan tingkat intelektual tinggi, melakukan perbuatan dengan penuh kesadaran, penuh perhitungan dan yang pasti adalah mereka melakukan perbuatan itu atas dasar kesenangan, kenikmatan yang sudah diperhitungkan dengan keuntungan secar bagi pribadi, organisasi dan golongan atau kelompoknya.

Dari sudut pandang kriminologi saat ini kejahatan dengan istilah Kejahatan Kontempore menduduki peringkat tinggi dipandang dari, (1). Pelakunya adalah tergolong Upper Class dalam arti mereka adalah intelektual yang berpendidikan tinggi, meduduki jabatan penting dalam pemerintahan maupun organisasi formal, orang yang berpengaruh di lingkungan masyarakat, tokoh masyarakat. (2). Berkaitan dengan alat atau sarana yang digunakan untuk mendukung perbuatan jahat umumnya adalah informasi teknologi dalam bentuk jaringan (network). (3). Berkaitan dengan korban (Victim) ternyata hukum Pidana yang bertalian dengan kejahatan yang dilakukan oleh Korporasi, dari sini sangat jelas terlihat Korbannya tidak dapat diperhitungkan. Dengan demikian dapat dikatakan bahwa Paradigma Viktimologi tidak hanya bertalian dengan kejahatan dalam arti klasik saja, akan tetapi juga menyangkut perbuatan lain diluar bidang hukum pidana, misalnya "Abuse of Power" atau korban pencemaran lingkungan dan lainnya. Maka oleh karena itu selayaknya penghukuman dengan menggunakan aplikasi economic analysis of law adalah tepat berdasarkan keadilan secara ekonomi.

\section{DAFTAR PUSTAKA}

\section{Buku:}

Abdulgani Karim, Pengaruh Agama Islam Terhadap Hukum Pidana Nasional, Kertas Kerja dalam Simposium Pengaruh kebudayaan/ Agama Terhadap Hukum Pidana - Badan Pembinaan Hukum Nasional; Binacipta 1975, 
Menangulangi Kejahatan Dengan Aplikasi Economic Analysis Of Law

A.Sanusi Has; Dasar- dasar Penologi; Rasanta, Jakarta;

Bushan J, Komadar, Journal: The Raise and Fall of a Major Finalcial Instrument, Univer sity of Westminster, 2007;

E.H.Sutherland dan Donald R. Cressey; Principles Of Criminology, sixth Edition, Lippincott Company, New York; 1960;

Fajar Sugianto; Economic Analysis Of Law, Seri Analisis Ke-ekonomian tentang Hukum; Kencana Prenada media; Jakarta; 2013;

Hans Kelsen; Teori Hukum Murni, dasarDasar Ilmu Hukum Normatif; Nusa Media, bandung, 2014;

Hermann Mannheim; Comparative Criminology; Houghton Mifflin Company; Boston, 1965;

Karya Para Pakar Hukum; Bunga Rampai Viktimisasi; Eresco Anggota IKAPI; Abndung, 1995;

Made Darma Weda; Kriminologi; Raja Grafindo Persada; Jakarta, 1996;

Moelyatno, Asas-Asas Hukum Pidana, Rineka Cipta, Jakarta, 2008;

Meuwissen; Pengembanan Hukum, Ilmu Hukum, Teori Hukum, dan Filsafat Hukum; Penerjemah; Prof.DR. B. Arief Sidharta, SH); Refika Aditama, Bandung; 2013;

Richard A. Posner, Economic Analysis Of Law, seventh edition, NewYork: Aspen Publishers, 2007;

R.A Koesnoen; Politik Penjara Nasional; Sumur Bandung, 1960.

Steven Shavell, Foundations Of Economic Analysis Of Law, London: The Belknap Press of Harvard University Press, 2004;

Sudarto, Hukum Pidana dan Perkembangan Masyarakat, Bandung: Sinar Baru, 1983;

Sudjono D; The Control Of Crime; Hukuman Dalam Perkembangan
Hukuman Pidana; Transito, Bandung; 1974;

Zainal Abidin, Hukum Pidana,(Jakarta: Sinar Grafika,2005).

Website:

http://www.dw.com/id/statistik-hukumanmati-di-asia/a-16731798 diakses pada Februari 2016

http://www.kompasiana.com/santarosa/extra ordinary-crime-extraordinary-law diakses pada Juli 2015. 